\title{
Developing Teacher Candidates' Self-Efficacy Through Reflection and Supervising Teacher Support
}

Glenda L. Black

Nipissing University

\begin{abstract}
The purpose of this study was to explore the complex cognitive and affective challenges of teacher candidates in their development toward self-efficacy in their teaching. Twenty-two teacher candidates recorded their challenges and thinking process during the last six weeks of their practicum. Following their placement, they completed a summative reflection, in which they noted changes in themselves and described when or if they felt confident as classroom teachers. Four themes emerge as the challenge or condition for their self-efficacy: effective classroom management, successful curriculum planning and implementation, positive rapport with students, and supervising teacher approval. This research suggests that teacher preparation program educators can support teacher candidates' self-efficacy by understanding the developmental stages of teachers, supporting critical reflection, and using motivational and descriptive feedback to improve practical skills.
\end{abstract}

Keywords: teacher self-efficacy; reflection; concerns-based stages model; transformational learning theory; and supervising teacher

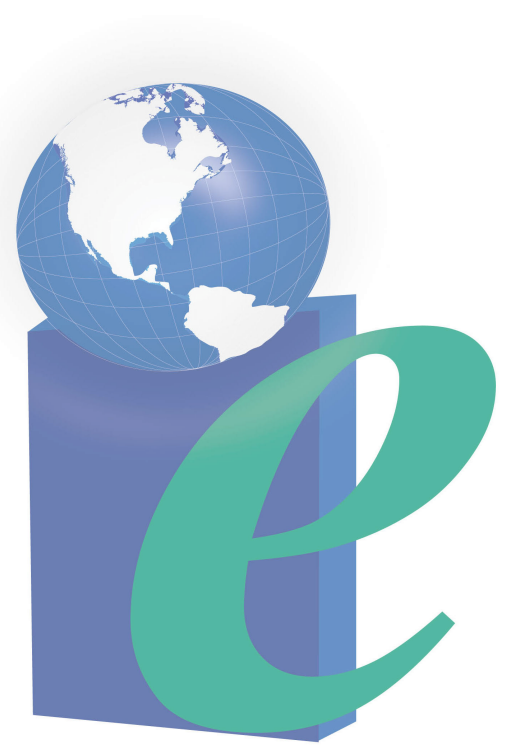




\section{Developing Teacher Candidates' Self-Efficacy Through Reflection and Supervising Teacher Support}

Meeting students' academic, social, and emotional needs is the cornerstone of student improvement. Teachers' confidence and competence is integral to improving students' academic performance (Bangs \& Frost, 2012; OECD, 2011). Self-efficacy gives teachers the confidence to effectively develop curriculum and respond to the social and emotional well-being of their students (Bandura, 2007; Hoy \& Spero, 2005). In recent years, self-efficacy, specifically teacher self-efficacy, has emerged as an identifiable area of study (Klassen, Tze, Betts, \& Gordon, 2011). However, an exploration of 218 articles between 1998 and 2009 reveals that research on the source of self-efficacy remains comparatively neglected (Klassen et al., 2011). The purpose of this study is to explore the complex cognitive and affective elements and challenges of teacher candidates' in their development toward self-efficacy in their teaching, to heighten awareness and create dialogue about teacher candidates' self-efficacy.

Reflective teachers set aside time to think about what they do in class, why they do it, and how their methods affect student performance. For example, they may examine a number of instructional techniques and theories as a means to meet the needs of their students. There is strong support for the practice of teacher candidates engaging in reflection to examine their beliefs about teaching to improve their practice, especially during field experience (Artzt \& Armour-Thomas, 2002; Britzman, 1991; Darling-Hammond, 1996; Dewey, 1933; Griffiths, 1996; Margolis, 2002; Moore, 2002; Tripp, 1993; Valli, 1993). An impressive body of research uses Fuller's (1969) seminal, concerns-based model, a stage-based approach to teacher development. While the literature situating the concerns-based model and teacher preparation programming is substantial (He \& Cooper, 2011; Marso \& Pigge, 1995; Watske, 2007), a gap exists in the intersection of the concerns-based model, teacher self-efficacy, and reflection.

Teacher candidates' learning-to-teach experiences and their progress toward self-efficacy and confidence in their ability as teacher practitioners was the focus of this study. Attention to the progress toward self-efficacy through the lens of transformational learning provides the opportunity to expand the view of teacher candidates' experiences. The study offers insights into teacher candidates' development toward self-efficacy and provides recommendations for teacher preparation programs regarding how confidence can be fostered and enhanced in teacher candidates. Before I offer a detailed description of the results and conclusions, I discuss the literature review, theoretical framework, and methods for the research.

\section{Literature Review}

\section{Self-Efficacy}

The construct of self-efficacy has its theoretical underpinnings in Bandura's $(1977,1997)$ social cognitive theory. Social cognitive theory posits that biology and the environment do not solely drive human behavior. Rather, humans act in intentional ways or exhibit "agency" (Bandura, 1997, p. 3). The term "“agency' refers to acts done intentionally" (Bandura, 1997, p. $3)$. The notion that personal beliefs contribute to life choices and eventual successes and failures is fundamental to social cognitive theory. In the field of self-efficacy, the work of Bandura's (1977) social cognitive theory is consistently identified as the lens through which the construct of self-efficacy is viewed (Capa, 2005; Henson, 2001; Vasquez, 2008). 
Bandura (1997) defines perceived self-efficacy as "beliefs in one's capabilities to organize and execute the courses of action required to produce given attainments" (p. 3). The concept of self-efficacy is complex (Tschannen-Moran \& Woolfolk Hoy, 2001). In their model of how teacher self-efficacy functions, Tschannen-Moran, Woolfolk Hoy, and Hoy (1998) use Bandura's $(1986,1997)$ four sources of influence on efficacy beliefs: mastery experience, verbal persuasion, physiological arousal, and vicarious experience.

Tschannen-Moran et al., (1998) identify mastery experience as the most powerful influence on self-efficacy. Mastery experience is the perception of an exceptional teaching performance, which contributes to the expectation of proficiency in future teaching. Efficacy is strengthened when the success is achieved early without too many setbacks or when success is achieved with little assistance on a difficult task. Conversely, efficacy is impaired if success is achieved through extensive external assistance or if the task is unimportant or too easy. Efficacy is lowered if the performance is perceived as a failure, which contributes to the expectation of failure for future performances.

Verbal persuasion is feedback in the form of encouragement or strategies to improve teaching (Tschannen-Moran, Woolfolk Hoy, \& Hoy, 1998). Interpersonal support from colleagues significantly contributes to novice teachers' perception of self-efficacy (TschannenMoran \& Woolfolk Hoy, 2007). Words of encouragement alone are limited in bolstering confidence in teaching. The strength of the persuasive words is dependent on the credibility of the persuader. The feedback can be general or specific. However, detailed feedback on teaching performance provides specific information on whether the performance is superior, adequate, or inferior relative to others teaching in similar context. Self-efficacy is likely to lower if the feedback is too harsh and unfocused. Constructive and focused feedback is likely to improve self-efficacy. A high level of guidance from supervising teachers positively correlates with teacher candidates' self-efficacy (Fives, Hamman, \& Olivarez, 2007; Knoblauch \& Hoy, 2008). Enthusiasm of the students, which is a form of social persuasion, is a constant source of positive information in developing self-efficacy in science teachers' (preservice and in-service) (Mulholland \& Wallace, 2001).

Physiological arousal is the level of emotional arousal in teaching situations and either adds or diminishes teaching competence. Tschannen-Moran et al., (1998) explain that teachers who feel relaxed when teaching perceive the emotion as an indication of proficiency and anticipate future success. High levels of physiological arousal may impede teaching and interfere with one's knowledge and skills. However, some individuals who experience arousal, such as increased heart and respiratory rate may perceive the arousal as positive or negative energy depending on the individual and circumstances. Attention and energy for teaching may be enhanced with moderate levels of arousal.

Vicarious experience is a source of efficacy that is influenced by observing others succeeding or failing (Tschannen-Moran et al., 1998). The point of vantage ranges from images during teacher education, professional literature, conversations in the staffroom, media images, and directly observing teachers teach. Watching skilled teachers, especially if they are admired and credible, affects the observer's confidence because they assess their ability through comparison with others in similar situations (Poulou, 2007). Beginning teachers who observe master teachers believe they are capable of success in a similar context. Likewise, observing a teacher fail erodes confidence in the ability to teach in a similar situation, unless the person feels 
they are more skilled than the person they observed. Thirty years have passed since Bandura (1986) introduced the sources of efficacy. Nevertheless, little is known about how the sources function (Henson, 2001; Klassen, et al., 2011).

Teacher self-efficacy is defined as the teacher's confidence in his or her ability to affect and promote student learning (Bandura, 2007; Dembo \& Gibson, 1985; Hoy, 2000). Similarly, researchers (Tschannen-Moran \& Woolfolk Hoy, 2001) propose self-efficacy gives teachers the confidence to inspire their students to achieve their potential and increase their own teaching aspirations. High levels of self-efficacy positively correlate with student achievement (Ashton \& Webb, 1986; Gibson \& Dembo, 1984; Leithwood, 2006; Moore \& Esselman, 1992). The impact of teacher self-efficacy on student achievement can be explained "as an expression of confidence that one's actions may lead to success and mastery over one-self and have a positive influence on others" (Bordelon, Phillips, Parkison, Thomas, \& Howell, 2012, p. 15). Teacher self-efficacy is context specific (Tschannen-Moran et al., 1998). Teachers' perceptions of efficacy are dependent on the subject or content they are teaching or the students in specific settings. For example, an efficacious secondary school physics teacher might feel inefficacious teaching an elementary science class. A confident teacher in a rural middle school might feel anxiety teaching in an urban middle school.

Hoy (2000) suggests that developing a lasting sense of efficacy in teacher candidates has implications for their future as early career teachers. . Teacher candidates' confidence increases when they experience success when faced with difficult circumstances, which in turn positively influences their self-efficacy (Yost, 2006). If teacher candidates feel confident to solve problems with a diverse group of students they are more motivated to persist in the future (Yost, 2006). Teacher educators and supervising teachers need to do more than make the teacher candidates feel good about their competence in teaching. Yost (2006) suggests, "the focus should be on raising competence [teach them what to do] and confidence [how to do it well] primarily through successful mastery experiences" in a variety of contexts (p. 61). For the purpose of this study, the terms self-efficacy and confidence have the same meaning.

\section{Concerns-Based Model}

Fuller's (1969) concerns-based model of teacher development is best described as "perhaps the most classic of stage theories in that it was meant to be relatively invariant, sequential and hierarchical" (Richardson \& Placier, 2001, p. 910). In her investigation of the concerns of beginning teachers, Fuller (1969) posits a "three phase developmental conceptualization of teachers' concerns" (p. 221). The three stages advance from: (a) preteaching-no-concern, (b) early teaching - concerns with self, to (c) late teaching-concerns with pupils (Fuller, 1969). In 1975, Fuller and Brown revised the developmental stages to progressing from: (a) concerns about self, (b) concerns about tasks or situations, and (c) concerns about impact on students.

Conway and Clark (2003) point to two strands of research that have grown out of this widely cited study. One strand is the "developmental dynamics" of teacher candidates and early career teachers (Conway \& Clark, p. 466). The second is the Concerns-Based Adoption Model (CBAM), used to measure, describe, and explain the process of change experienced by teachers involved in implementing the changes (Anderson, 1997; Hord \& Hall, 2000). Conway and Clark extend the concerns-based model by claiming that teacher candidates' progress on both an 
outward journey, following Fuller \& Brown's (1975) three stages of development (), and on an inward journey of self-development. The inward journey focuses a teacher candidate's attention on her or his "self-as-teacher," as related to his or her hopes and fears (Conway \& Clark, 2003, p. 470). Insight into one's self is achieved through reflection.

\section{Reflection}

Strong support for reflective practice is evident in the literature (Artzt \& ArmourThomas, 2002; Britzman, 1991; Darling-Hammond, 1996; Dewey, 1933; Griffiths, 2000; Tripp, 1993; Margolis, 2002; Moore, 2002). Reflecting on practice is a strategy to self-evaluate and make judgments on knowledge, capacity, competence, and confidence as a teacher. According to Boyd and Fales (1983), "reflective learning is the process of internally examining and exploring an issue of concern, triggered by an experience, which creates and clarifies meaning in terms of self, and which results in a changed conceptual perspective" (p. 100). Depending on their development as a teacher, candidates' concerns are related to self, tasks, situations, or impacts on students (Fuller \& Brown, 1975; Putney \& Broughton, 2010) activated during their mastery experience, their teaching practicum. Bandura (1986) supports self-reflection, as it positively contributes to altering a person's thinking and actions. Fundamental to the concept of selfefficacy is the ability self-reflect: to make judgments and develop a course of action (Bandura, 1989).

In their analysis of the literature, Atkins and Murphy (1993) reveal agreement among scholars that there are stages of reflection. However, the number of stages differs among models. For example, Mezirow (1981) identifies seven stages and Schon (1991) acknowledges only three stages of reflection. Atkins and Murphy (1993) discover that all reflection models are hierarchical, but the differences are largely due to terminology. Their synthesis of the literature identifies three stages of the reflective process: (a) The first stage "is triggered by an awareness of uncomfortable feelings and thoughts," (b) which is followed by "a critical analysis of feelings and knowledge," and then (c) the development of a "new perspective" on the situation (p. 1190). Further analysis and synthesis of the literature identifies the cognitive and affective skills for critical reflection: description [recollect events accurately], critical analysis, self-awareness, synthesis, and evaluation (Atkins \& Murphy, 1993).

\section{Theoretical Framework}

Adulthood comes with the recognition that change is constant and there are no enduring truths. It is, therefore, imperative, in Taylor's (2007) words, to "develop a more critical worldview as we seek ways to better understand our world" (p. 5). The theoretical framework for this study draws upon the theory of adult learning known as transformative learning.

\section{Transformational Learning Theory}

Transformational learning theory is an adult learning theory based on the fundamental principle that adults make meaning and learn from personal experiences (Mezirow, 1991). It is part of a developmental process grounded in communication, where new meanings can be created through the reinterpretation of experiences, filtered through one's expectations, beliefs, and assumptions (Taylor, 2007). According to Mezirow (1996), meaning structures are based on meaning schemes and meaning perspectives. Meaning schemes are specific knowledge, beliefs, value judgments, and feelings; meaning perspectives are general frames of reference, 
worldviews, or personal paradigms (Mezirow, 1996). Meaning perspectives are uncritically acquired through the process of socialization and acculturation with parents, teachers, and mentors. Mezirow (1997) contends that meaning perspectives become the lens through which one views and evaluates the world, and although it provides one with direction and meanings, it also distorts one's thoughts and perceptions. To understand how meanings evolve, Mezirow (2000) describes three-phases of transformational learning involving content, process, and premise stages.

The content stage begins with dissonance created by recognizing a new situation or information as inconsistent with previous understandings. Mezirow (2000) describes this as a "disorienting dilemma" (Mezirow, 2000, p. 22), prompting one to engage in the process stage characterized by "self-examination" due to "feelings of fear, anger, guilt or shame" (Mezirow, 2000 , p. 22). The process stage is pivotal because it can have a variety of outcomes. According to the dual process theory described by Gregoire (2003), two possible routes exist for processing information: (a) a systematic processing route requiring effortful cognitive processing and potential long-term change, or (b) a peripheral processing route involving automatic, low-level processing, producing short-term or no change. Finally, the premise stage is characterized by the critical assessment of one's assumptions.

The critical assessment stage of transformational learning has received significant attention from researchers. The ability to reflect critically appears to be a developmental process linked to experience. Merriam (2004) asserts, "mature cognitive development is foundational to engaging in critical reflection and rational discourse necessary for transformative learning" ( $p$. 65), and this gives credence to the notion of providing teacher candidates with opportunities and support to reflect critically. Gregoire (2003), in her analysis of conceptual change, further notes meaningful change is difficult and requires sufficient motivation, ability, and a supportive context to overcome the convenience of peripheral persuasion routes where discrepant information is simply assimilated into pre-existing frameworks or discarded altogether. In the absence of required support and a threshold level of readiness and ability, an individual may feel threatened rather than challenged, and consequently, be unable to accommodate new information, with no resultant belief changes. These findings suggest that without a supportive environment and opportunity to experience and explore new perspectives, transformational learning is unlikely.

\section{Method}

The study followed a qualitative research design to provide rich description and in-depth insight into teacher candidates' self-efficacy experience. Theorists and researchers call for more qualitative research on self-efficacy (Coladarci \& Breton, 1997; Klassen et al., 2011; TschannenMoran \& Hoy, 2001; Tschannen-Moran et al., 1998; Wheatley, 2002). The current study addresses the following research questions: (a) What obstacles or challenges do teacher candidates experience during their practicum on their journeys toward self-efficacy? (b) What cognitive and affective changes do teacher candidates experience on their journeys toward selfefficacy?

\section{Data Sources}

The study follows a hermeneutical phenomenological approach by using the lived experiences (phenomenology) of the teacher candidates and interpreting their "texts" of teaching 
experiences (hermeneutics) (Denzin \& Lincoln, 2000; van Manen, 1990, 1997). Hermeneutic phenomenology attempts to understand a phenomenon (i.e., teacher candidates' self-efficacy) by interpreting the subjective experiences of individuals (Kafle, 2011). The texts or written communications from the teacher candidates were used to interpret and find meaning in the candidates' experiences (van Manen, 1990, 1997). The communications or data from the teacher candidates were collected over a 3-month period (March - May 2013), and included their lesson plans with recorded reflections from their 6 weeks of practicum followed by 4 weeks of instruction on campus. The data included the teacher candidates' open-ended impressions and feelings around their practical experiences and their perceptions of confidence in their teaching practices. During the 6-week practicum, the teacher candidates recorded their reflections directly on their lesson plans by reflecting on what went well, what they were able to achieve, and how their learning might influence future situations. Following the practicum, the teacher candidates created a summative reflection by reviewing their lesson plan reflections and noting changes in themselves and they described when or if they felt confident as classroom teachers.

\section{Participants}

The 22 (16 female and six male) teacher candidates invited to participate were from the same teacher education program in their final semester of the program. All participants were White, ranging in ages from 23 to 36, and were pursuing qualifications in the intermediate-senior divisions (Grades 7-12). The sample represents a range of teaching experiences: rural, urban, public, Catholic public, First Nations, elementary, and secondary school settings. While the size of the sample restricts generalizability of the findings, this sample may be reflective of Ontario teacher candidates.

\section{Data Analysis}

Following a general inductive technique for hermeneutical phenomenological research (van Manen, 1990, 1997), the method of analysis included Miles and Huberman's (1994) sequential three-step process: (a) data reduction (review data, develop codes, code data to summarize, sort, and organize), (b) data display (organize and compress data into matrix), and (c) conclusion drawing/verification (make meaning of the data by noting patterns, interpretations, triangulation of sources). Using the documentation (in the form of lesson plans detailing instruction and assessment, reflections on the lesson, and summative reflections), I conducted constant comparative analysis of data (Glaser \& Strauss, 1967; Handsfield, 2006). I organized the data into categories and emerging themes to bring meaning to the data. The categories relate to studies described in the literature and analyzed through the lens of the transformational learning theory. Subsequently, conclusions were drawn in regard to the research questions, which proceeded primarily from using a network style of data display that revealed connections and relationships. Verification of the results involved constant comparison of data to test the sturdiness of the results.

\section{Results}

Twenty of the 22 candidates stated that by the end of the last practicum for the program they felt confident as a teacher. The two candidates who did not perceive themselves as confident believed more experience was necessary. As Parker (pseudonym), one of the two candidates explains, "Examining my reflections you can see some changes over time. In many areas I have achieved a great deal of success, but there are a great deal of areas that still require significant 
improvement." He continued by explaining, "I would liken this to musical achievement in many respects. Although through practicing and performing, you can notice notable and quantifiable improvement, you are never fully satisfied, and grow pickier with your abilities as you improve" (personal reflection, May 15, 2013).

The remaining 20 candidates felt confident as teachers at some point during their practicum. The results are presented and discussed in relation to the themes emanating from the two research questions. Based on their lesson plan reflections and summative reflections, four themes emerged as the challenges or obstacles that developed in their teaching self-efficacy: (1) effective classroom management, (2) successful curriculum planning and implementation, (3) positive rapport with students, and/or (4) supervising teacher approval. The candidates' cognitive development improved, as evidenced in their use of reflection to put theory into practice; affective changes were dependent on the situation: candidates' comfort with content, planning, students, or classroom management. Pseudonyms were used in place of all the names of the teacher candidates.

\section{Challenges or Obstacles}

Classroom management. Confidence was evidenced in the candidates' successes with classroom management. All the teacher candidates reflected on classroom management. The differences were in the type of management issues, whole class or individual students, and how they approached the challenge. For example, early in her placement Ariel believed she needed to be a friend to her high school students, especially disruptive students. She explains, "I used to be such a pushover for the sake of not being liked by my students. I learned that intervention strategies that are firm, yet fair for classroom management are absolutely necessary to counteract the actions of disruptive students" (personal reflection, May 17, 2013).

Avery problem-solved her management issue by developing a strategy to "re-gain everyone's attention" during cooperative learning situations, "I decided that I was going to try a management technique that I had imagined over the previous weekend" (personal reflection, May 6, 2013). She went on to explain her strategy of using the code word squirrel "because in the movie $U p$ there is a dog character that says that word every time he thinks he sees a squirrel his attention is diverted" (May 6, 2013). Avery explains that the code was used for the remainder of her practicum with success. The teacher candidates progressed in their teacher development to recognize the connection between classroom management and curriculum planning and implementation, "I have learned that the more engaged the students are in the lesson, the less likely they will misbehave" (Adrien, personal reflection, May 8, 2013). Similarly, Casey simultaneously planned engaging lessons and behavior expectations, because the students "knew [her] my rules and expectations when it came to group work" (Ariel, personal reflection, May 9, 2013).

Curriculum planning and implementation. In reference to her history lesson, Casey reflects on her emphasis on curriculum planning and implementation, "This lesson made me feel competent and confident as a teacher and taught me that in my future classroom I will place emphasis on cooperation, collaboration, interactive activities, engaged learners, and critical thinking" (personal reflection, May 9, 2013). Most of the teacher candidates' lesson plans showed they were differentiating their instruction (i.e., using inquiry method, cooperative learning, various groupings, and multiple intelligences for planning instruction and assessment, 
etc.) to meet the learning needs of their students. Following the concerns-based model, teacher candidates progressed from concerns about self (their teaching techniques), to task (the content they are teaching), and then to concern for their impact on students (Fuller \& Brown, 1975). For some candidates, their level of concern stalled at the content stage because of their lack of knowledge with the content area they were responsible to teach. For example, Chris states, "At first, my main focus was the content I was teaching. I concentrated so hard on making good lessons, but I found it hard to be creative in the math classroom as well as to learn and teach the content." Chris continues, "I was learning and teaching the content, filling in the lesson plans, and managing classroom behavior. I was struggling to get through" (personal reflection, May 13, 2013). Cam, with a music teachable says, "I was completely out of my element not teaching music, and responsible for teaching geography, math, and a little bit of art" (personal reflection, May 17, 2013). Using Tschannen-Moran et al.'s (1998) mastery experience source of selfefficacy, Chris's and Cam's progress toward self-efficacy was impaired by the difficulty of the task to teach subjects they did not have the background to teach.

The transformational learning theory (Mezirow, 1991) may explain the candidates' effortful cognitive processing (Gregoire, 2003) to confront their "disorienting dilemmas" (Mezirow, 2000, p. 22), specifically their teaching challenges, which may assist the candidates to establish long-term teaching practices. Cam describes her process to improve:

Well, the first thing I did was to seek help. I had already gone to my supervising teacher for help and she did not help me in the slightest. So, I went to my fellow classmates. I asked [student's name] for help on how to figure out the conversion. He was kind enough to take the time to write out a way to show my students how to figure out a conversion. For two days, my Grade 8s and I worked on conversions until everyone understood how to use the conversion factor. This was the lesson that made everything clear for me. (personal reflection, May 17, 2013)

Cam went on to explain the process she followed to learn the content and how to teach her students. She described the process as an "ah-ha" experience.

For 14 of the 22 candidates, self-efficacy was linked to their students' learning, engagement, and assessment. For example, Kim says, "I enjoyed interacting with the students and keeping them engaged in the content." Kim continues, "When it came to marking their test I had a lot of pride when I discovered the whole class got over $80 \%$ on the osmosis section of the quiz" (personal reflection, May 6, 2013). Kelly experienced confidence in her teaching through her students' success after she administered an assessment her supervising teacher thought was too hard; she says, "I did give that test to the Grade 9 science class and they had an average of $88 \%$. I had taught the material effectively, students had a solid understanding of the concepts, and I was successful in engaging them" (personal reflection, May 14, 2013).

Rapport with students. The establishment of positive rapport or of making connections with students at risk was the indicator of self-efficacy for five of the 22 teacher candidates. All the teacher candidates' lesson plan reflections indicated concern about persevering with individual students with academic or behavioural issues and about making connections with students at risk. Reese, whose supervising teacher was a guidance councillor, describes her "unbelievable experience" when a student-at-risk requested to speak specifically to her. "He took the advice and the encouragement I said to him to heart and I could tell he truly looked up to me 
as a role model" (Reese, personal reflection, May 6, 2013). Robin describes a number of "moments" with students. A situation with her Grade 9 science class with an at risk student who was "frequently off task and would complete few assignments," struck her as significant when the student directed other students to "be quiet, I'm listening to Ms. Riley" (Robin, personal reflection, May 7, 2013).

Rory describes her relationship with a student at risk, identified with an Attention Deficit Hyperactivity Disorder, who had a 2-year-old, and was pregnant while attending her class. "The moment that acted as the turning point in my success and confidence as a classroom teacher happened on the very last day." This moment was when a student told her she "was going to miss [Rory's] ability to keep her engaged in her music studies and actively coming and participating in class." Rory says, "[I will] continue to identify with each of my students to build solid relationships that will benefit my ability teach to the interests, abilities and skills of my students." In their summative reflections, the teacher candidates reflected on how their teacher development progressed from a focus on their teaching to their impact on students. For example, Rene stated, "After reviewing my reflections from my 6-week placement, over time ... I focused a lot in my reflections on how I interacted with students, and less about my teaching methods" (personal reflection, May 10, 2013).

Supervising Teacher. None of the teacher candidates' lesson plan reflections recorded concerns about their supervising teacher, which is not surprising because the supervising teacher reviewed their lessons plans, which included their lesson reflections. Additionally, supervising teachers were required to evaluate the teacher candidate's teaching performance, and the candidates did not want to influence their evaluation by commenting on their supervising teacher. Nevertheless, the candidates' summative reflections, which were not reviewed by the supervising teacher, revealed that the supervising teacher's approval directly influenced their self-efficacy as a teacher. For example, Mich states, "My second placement went waaaay better! I was comfortable with my supervising teacher, she was a hard worker but also very realistic so I wasn't as intimidated" (personal reflection, May 7, 2013).

The verbal persuasion in the form of specific, positive feedback (Tschannen-Moran et al., 1998) contributed to perceptions of self-efficacy. Morgan describes support from her supervising teacher; she "believed I was capable of the challenge" (personal reflection, May 7, 2013). Mel states, "My supervising teacher was very honest about my strengths and weaknesses, and gave me ample feedback on a daily basis. This constant dialogue really helped boost my confidence levels and helped me to excel as a teacher" (personal reflection, May 15, 2013). Mackenzie explains that her affirmation as "an educator" came from her supervising teacher, "He had commented on how he felt the students respected me because of the confidence I demonstrated when answering the many, many questions" (personal reflection, May 10, 2013). Other comments on their supervising teachers included, "As soon as the class ended my supervising teacher was very thrilled with how the class went" (Ariel, personal reflection, May 17, 2013). Another states, "My supervising teacher praised me on the success of the activity I planned" (Avery, personal reflection, May 6, 2013).

\section{Cognitive and Affective Changes}

Critical reflection. Toward the end of the teacher candidates' placement, their cognitive development and understanding of selves as teachers and reflective practitioners improved. For 
example, all the lesson plan reflections and summative reflections contained elements of critical reflection. Pat stated in his second last week of practicum, "As a classroom teacher, I will always be able to find areas of improvement in my lessons, and will then develop strategies for improving the lesson in the future." He continues by explaining, "This lesson was the first time I felt as though reflective practice was a natural end to the lesson, rather than an additional requirement" (personal reflection, May 15, 2013). In her summative reflection, Parker states, "My reflections shifted from a journal type entry to being a specific do and do not do in the future. I wrote only for myself and that allowed me to be honest" (personal reflection, May 15, 2013).

Although the teacher candidates demonstrated elements of critical reflection, there was however, inconsistency between the lesson plan details, the reflections, and perceived selfefficacy. For example, the lesson plan details for Alex's high school math class generally showed whole group instruction followed by individual application tasks from the textbook. Alex's lesson plan reflections mostly note concern for self or the task, yet reports confidence in his teaching. For example, his lesson plan reflections note concerns such as, "Do not start talking until I have the attention of all the students. Need to work on learning the names of my students." Similar reflections continued until the end of the placement, "I should wait until announcements are over before handing out tests. Need to have work prepared for those who finish early. Try to avoid using words like 'alright, okay, yup' - it will save time in my lesson" (personal reflection, March 19, 2013). In his summative reflection, he perceives confidence in his teaching as evidence by his success in managing the class.

Most teacher candidate's lesson plans described lessons that engaged the students and their reflections referenced results from assessments and revealed concern for students' learning early in their placements. For example, Amal, another candidate teaching high school math, records, "Seems like everyone needs a bit of a refresher with rounding after bell work. By the end of the diagnostic assessment most seemed to do alright. Need to watch [students' names]they are stuck with hype, always being 'c'—next time, avoid the formula with them altogether." She continues by exclaiming, "H.S has come to class 5 days in a row, a new record! The icing on the cake - he stayed to finish up his questions and did not pack up in a hurry and leave-like normal" (personal reflection, May 7, 2013).

As a condition of transformational learning, the candidates demonstrated the high level of cognitive effort needed for long term change through what Gregoire (2003) terms accomodation. Transformational, long-term change requires motivation, ability, and a supportive context in order to challenge deeply held assumptions. Permanent change is not a simple task, and Kreber (2004) notes the greater importance of critical reflection around goals and purposes in education when compared to reflection around intructional and pedagogical knowledge. She emphasizes the need to be more concerned with why we teach rather than what or how we teach. This sensitivity to the consequences of one's actions as they impact other people was summed up by a teacher candidate in her reflection, "As a teacher I do not think that success should only be defined through moments that went well in your teaching. My definition of success is the way one addresses difficult situations to find positive and effective solutions" (Parker, personal reflection, May 15, 2013).

Theory-informed practice. Some of the candidates teaching proficiency developed to the stage of using theory to inform practice, beyond differentiation and multiple intelligences. In 
her reflection of a lesson her supervising teacher felt was "risky," Sam declares, "I felt it challenged the students and seeing them all rise to the challenge was exciting. It showed how true Pygmalion Theory really is. I had high expectations of the students and they exceeded them" (personal reflection, May 8, 2013).

Emotions. Teacher candidates' affective states ranged from frustration, terror, pride, sense of belonging, and everything in between in their journeys toward confidence and selfefficacy. Tschannen-Moran et al., (1998) make specific reference to the physiological or emotional arousal in teaching situations as feeling "butterflies" as a source or influence for selfefficacy, which can either enhance or reduce teaching competence (p. 229). Taylor's emotions progressed from jitters to confidence, "I was comfortable in the class, but every day I still managed to have butterflies in my stomach. It was Week 5, when I think the butterflies finally flew away and I was able to realize I am a teacher" (personal reflection, May 10, 2013).

Most candidates expressed feelings of pride in their classroom success: "I felt so proud that my own idea was so effective, and at that point I truly felt like a teacher because I felt that I had implemented my own management technique successfully" (Teagan, personal reflection, May 15, 2013). Toby developed a sense of belonging in a First Nations school during her participation in their professional development days where she learned about Canadian Aboriginal culture, residential schools, and made a hand drum. In her words, "During these PD sessions I felt I really connected and related with the values of First Nations culture and was eager to learn and experience more" (personal reflection, May 13, 2013). Self-efficacy was expressed in their teaching confidence: "I would say that the biggest thing that changed for me was my confidence level in my teaching. I found that as time went on I felt more comfortable in front of the class and I feel that my teaching reflected that" (Vic, personal reflection, May 8, 2013).

\section{Discussion}

The findings from this study correlate with the literature on teacher self-efficacy, in that teacher candidates, who perceived themselves as confident in their lesson plan reflections and summative reflections, created engaging learning environments for their students (Bordelon et al., 2012; Tschannen-Moran \& Woolfolk Hoy, 2001; Yost, 2006), These teacher candidates described in detail the teaching and learning they developed and implemented, which was mostly creative, innovative, and attentive to the diverse needs of their learners.

There is no consensus among researchers on how best to measure teacher-efficacy. Substantial quantitative research and related literature on teacher self-efficacy exists. However, most of the quantitative research provides only the teacher candidates' perspective-self-report on self-efficacy. The research discussed in this article used two elements related to teacher candidates' teaching practice- 6 weeks of lesson plans with detailed planned instruction and assessment, reflections on the lesson, and a summative reflection on their placement experience. The missing component is direct observation of the lesson by someone with teaching expertise. Triangulating the teacher candidates' perception of self-efficacy with their lesson plan and reflection (self-report) would provide a holistic perspective on candidates' self-efficacy. The need to triangulate lesson plan, reflection, and observation was evident in the reflection from Alex, who reported self-efficacy in his math class when he successfully managed his class. His perception of self-efficacy was based on one component of teaching-managing student 
behavior and did not consider student learning as a result of his teaching. His lesson plans provided some insight into his teaching practices and his reflections showed he focused mostly on class management. Direct observation of Alex's teaching would provide understanding of Alex's level of concern (self, task, students) and confirm his perception of self-efficacy.

Nevertheless, most studies that confirm Bandura's (1997) theory, that mastery experience is the strongest source of self-efficacy, used quantitative data, mostly in the form of self-efficacy surveys (Usher \& Pajares, 2009). The current study provides qualitative support for Bandura's claim and adds to the theory by demonstrating how the affective domain, physiological arousal, the level of emotional arousal during teaching situations, influenced self-efficacy and teaching confidence (Tschannen-Moran et al., 1998). Consistent with Tschannen-Moran et al., the candidates' high levels of emotional arousal (i.e., extreme frustration or terror) interfered with their perception of self-efficacy. However, a moderate state of arousal, described as "butterflies" contributed to the process of feeling self-confident.

A source of significant influence, evidenced in all the candidates' reflections on the candidates' self-efficacy was verbal persuasion in the form of feedback from their supervising teacher (Tschannen-Moran et al., 1998). Similar to previous studies (Fives et al., 2007; Knoblauch \& Hoy, 2008; Mulholland \& Wallace, 2001) the candidates' perceptions of selfefficacy correlated with supervising teachers' comments. The candidates' perceptions of selfefficacy were higher when they received constructive, positive feedback followed up with motivational comments from their supervising teacher. Lower perceptions of self-efficacy were evident among the candidates when supervising teacher comments were harsh or absent.

Further, the data revealed the affective component, physiological arousal, was highly dependent on the verbal persuasion, the type of feedback they received from their supervising teacher. In other words, support or lack of support from the supervising teacher significantly influenced teacher candidates' emotional states. Praise, when appropriate and detailed, and descriptive feedback from their supervising teacher strongly influenced the development of confidence and self-efficacy.

The missing source of self-efficacy in the data was vicarious experiences. The candidates' observations of their supervising teachers or other teachers (master or novice) were not evidenced in the lesson plans or reflections. Thus, a valuable influence for developing teacher candidates' self-efficacy was not studied. In the last 6 weeks of their practicum placement (when the data was collected for this study), the candidates were responsible for teaching a second day. Modeling serves as an effective tool for promoting a sense of personal efficacy. Modeling teaching (vicarious experience) and providing constructive feedback (verbal persuasion) has the potential to improve teaching skills and self-efficacy (Fives et al., 2007; Knoblauch \& Hoy, 2008). Supervising teachers who share their professionalism, pedagogical ideas, and competence should be trained for the mentoring role to provide supportive feedback and effective communication.

Although the concerns or challenges of the teacher candidates could be categorized as self, task, and students (Fuller \& Brown, 1975), the responses from the teacher candidates go beyond the academic learning of the students. All the teacher candidates mentioned students at risk and their problem-solving of how to reach these students beyond their academic needs to meeting their learners' social and emotional needs. 
The results support the notion that engaging in reflection or self-examination is a critical stage to transformational learning (Mezirow, 2000, p. 22). Consistent with the literature (Conway \& Clark, 2003), the opportunity to reflect assisted the candidates in understanding and questioning their personal beliefs and values. Congruent with Conway and Clark (2003), the candidates, through reflection, embarked on emotional inward journeys on their development toward competence and confidence. Similar to Nolan and Sim (2011), the reflective process facilitated the teacher candidates' learning and identification of perceived self-efficacy. In agreement with Yost (2006), teacher candidates acknowledged their need of the knowledge and skills for reflection and the time to reflect on their practice.

\section{Implications and Conclusions}

To assist teacher candidates in their development toward confidence and teacher self-efficacy, the following recommendations for teacher preparation program faculty and supervising teachers are based on the results from this study and a review of literature on teacher self-efficacy, teacher developmental concerns, and reflection. Teacher preparation program faculty and supervising teachers should provide instruction and assist teacher candidates in their development toward self-efficacy by using critical reflection, understanding of developmental stages of teachers, and motivational and descriptive feedback to improve practical skills.

\section{Develop Reflection Skills}

Teacher preparation program faculty and supervising teachers are encouraged to provide explicit instruction on reflection skills to heighten candidates' awareness of the complexity of student learning and behaviour (Putney \& Broughton, 2010). By developing reflective skills, candidates are more likely to progress beyond recording past experiences of a journal style of writing and move toward identifying problems and developing action plans for future lessons, with the goal of increasing self-efficacy in their teaching. With the goal of empowering the teacher candidates, introducing a reflection framework will assist teacher candidates to selfassess and enhance their understanding of their progression through the levels of reflection, (Nolan \& Sim, 2011). Teacher preparation programs need to establish criteria for assessing critical reflection (Larivee, 2008; Smith, 2011). Although some argue that measuring reflection stifles authentic reflective practice (Beveridge, 1997; Sumsion \& Fleet, 1996), a measure is necessary to assist candidates in their self-assessment. Teacher preparation program faculty and supervising teachers need a framework to support candidates' development of critical reflection. The reflective evaluation framework, with six levels of reflection as presented by Nolan and Sim (2011), shows potential for facilitating teacher candidates in their reflection development. Evaluation of reflection is based on the levels of reflection: returning to the experience, attending to feelings, association, integration, validation, appropriation, and outcome of reflection (action, affective, perspectives) (Nolan \& Sim, 2011). Using the reflective evaluation framework, faculty and supervising teachers could assist candidates in developing their reflection skills using the criteria, thus facilitating teacher candidates' transformational learning.

\section{Understanding Stages of Teacher Development}

It is important to enhance teacher candidates understanding of the stages of teacher development. Critical to candidates' self-efficacy is their understanding of teachers' progression toward self-efficacy as a normal process, which requires knowledge and practice. Assist teachers in training to understand that the process of moving from self, task, to student (Fuller \& Brown, 
1975), which in turn develops into teacher self-efficacy is normal. Teacher candidates using reflection will be able to self-assess their teacher development on their journey toward selfefficacy.

\section{Supervising Teacher and Teacher Candidate Relationship}

The relationship between the teacher candidate and supervising teacher, and subsequent comments and feedback had a powerful effect on the teacher candidates' confidence, especially on the teacher candidates' affective outcome, a "change in attitude or emotional state" (Nolan \& Sim, 2011, p. 124). For all the teacher candidates in this study, feelings of confidence were dependent on the affirmation or criticism of teacher candidates' supervising teacher. The teacher candidates frequently questioned their ability to be a teacher, or their ability to be a successful teacher. The teacher candidates' reflections showed frustration and doubt with their knowledge and skills. Supervising teachers have the potential to inspire confidence through their support and words of encouragement for motivation and descriptive feedback on how to improve their teaching practice to meet the diverse population of students in their future classrooms.

Further, there needs to be a strong connection between the teacher preparation programs and practicum (NCATE, 2010). Strategies for strengthening the support for candidates might include having supervising teachers and faculty meet, either face-to-face or on a social media forum and professional development and support for supervising teachers to provide guidance for effective mentorship and coaching of teacher candidates. The evidence underscored the importance of supervising teachers providing feedback, both motivational and descriptive to assist teacher candidates in their teacher development.

\section{Future Research}

Results from this research are consistent with previous research on teachers' selfefficacy, teacher development, and reflection. However, this research represents only twenty-two teachers from one teacher preparation program, more research in different teaching contexts is required. The data collected for this research explored two perspectives - the lesson plans with planned instruction and assessment, reflections from the lessons, and a summative lesson. The missing component was direct observation of the lessons and reflections to triangulate the findings. Researchers would benefit from considering investigations on the intersection of teacher self-efficacy, concerns-based model of teacher development, and reflection.

The study offers insights into teacher candidates' development toward self-efficacy and provides recommendations for teacher preparation programs regarding how self-efficacy can be fostered and enhanced in teacher candidates. Specifically, intentionally intersecting the reflection levels of self-analysis with the teacher developmental stages as a learning tool for professional practice has the potential to facilitate teacher candidate's progression toward confidence and competence-self-efficacy. The approach is an action outcome for an advanced level of reflection (Nolan \& Sim, 2011), and a new approach. 


\section{References}

Anderson, S. E. (1997). Understanding teacher change: Revisiting the concerns based adoption model. Curriculum Inquiry, 27(3), 331-368. doi: 10.1111/0362-6784.00057

Artzt, A. F., \& Amour-Thomas, E. (2002). Becoming a reflective mathematics teacher: A guide for observations and self-assessment. Mahwah, NJ: Lawrence Erlbaum Associates.

Ashton, P. T., \& Webb, R. B. (1986). Teacher efficacy and student achievement. New York, NY: Longman.

Atkins, S., \& Murphy, K. (1993). Reflection: A review of the literature. Journal of Advanced Nursing, 18(8), 1188-1192. doi: 10.1046/j.1365-2648.1993.18081188.x

Bandura, A. (1977). Self-efficacy: Toward a unifying theory of behavioral change. Psychological Review, 84(2), 191-215. doi: 10.1037/0033-295X.84.2.191

Bandura, A. (1986). Social foundations of thought and action: A social cognitive theory. Englewood Cliffs, NJ: Prentice Hall.

Bandura, A. (1989). Human agency in social cognitive theory. American Psychologist 44(9), 1175-1184. doi: 10.1037/0003-066X.44.9.1175

Bandura, A. (1997). Self-efficacy: The exercise of control. New York, NY: Freeman.

Bandura, A. (2007). Much ado over a faculty conception for perceived self-efficacy grounded in faulty experimentation. Journal of Social and Clinical Psychology, 26(6), 641-658. doi: $10.1521 /$ jscp.2007.26.6.641

Bangs, J., \& Frost, D. (2012). Teacher self-efficacy, voice and leadership: Towards a poly framework for education international. Education International Research Institute, University of Cambridge Faculty of Education. Retrieved from http://www.educ.cam.ac.uk/centres/lfl/projects/teacherleadership/EI teacher_selfefficacy_voice leadership_Feb2012-1.pdf

Beveridge, I. (1997). Teaching your students to think reflectively: The case for reflective journals. Teaching in Higher Education, 2(1), 33-42.

Bordelon, T. D., Phillips, I., Parkison, P. T., Thomas, J., \& Howell, C. (2012). Teacher efficacy: How teacher rate themselves and how students rate their teachers. Action in Teacher Education, 34(1), 14-25. doi: 10.1080/01626620.2012.642282

Boyd, E. M., \& Fales, A. W. (1983). Reflective learning key to learning from experience. Journal of Humanistic Psychology, 23(2), 99-117. doi:10.1177/0022167883232011

Britzman, D. P. (1991). Practice makes practice: A critical study of learning to teach. Albany NY: State University of New York Press.

Capa, Y. (2005). Factors influencing first-year teachers' sense of efficacy. (Unpublished doctoral dissertation). The Ohio State University, Ohio. 
Coladarci, T., \& Breton, W. A. (1997). Teacher efficacy, supervision, and the special education resource-room teacher. Journal of Educational Research, 90(4), 230-30. doi:10.1080/00220671.1997.10544577

Conway, P. F., \& Clark, C. M. (2003). The journey inward and outward: A re-examination of Fuller's concerns-based model of teacher development. Teaching and Teacher Education, 19(5), 465-482. doi:10.1016/S0742-051X(03)00046-5

Darling-Hammond, L. (1996). The quiet revolution: Rethinking teacher development. Educational Leadership, 53(6), 4-10.

Dembo, M. H., \& Gibson, S. (1985). Teachers' sense of efficacy: An important factor in school improvement. The Elementary School Journal, 86(2), 173-184. Denzin, N. K., \& Lincoln, Y. S. (Eds.). (2000). Handbook of qualitative research $\left(2^{\text {nd }} \mathrm{ed}\right.$.). Thousand Oaks, CA: Sage.

Dewey, J. (1933). How we think: A restatement of the relation of reflective thinking to the educative process. Chicago, IL: Henry Regnery Co.

Fives, H., Hamman, D., \& Olivarez, A. (2007). Does burnout begin with student-teaching? Analyzing efficacy, burnout, and support during the student-teaching semester. Teaching and Teacher Education, 23(6), 916-934. doi:10.1016/j.tate.2006.03.013

Fuller, F. F. (1969). Concerns of teachers: A developmental conceptualization. American Educational Research Journal, 6(2), 207-226.

Fuller, F. F., \& Brown, O. H. (1975). Becoming a teacher. In K. Ryan (Ed.), Teacher education: $74^{\text {th }}$ yearbook of the National Society of Education (pp. 25-52). Chicago, IL: University of Chicago Press.

Gibson, M. H., \& Dembo, M. (1984). Teacher efficacy: A construct validation. Journal of Education Psychology, 76(4), 569-82. doi:10.1037/0022-0663.76.4.569

Glaser, B., \& Strauss, A. (1967). The discovery of grounded theory: Strategies for qualitative research. Chicago, IL: Aldine.

Gregoire, M. (2003). Is it a challenge or a threat? A dual-process model of teachers' cognition and appraisal processes during conceptual change. Educational psychology review, 15(2), 147-179. Retrieve from http://search.proquest.com/docview/758478270/fulltextPDF/2E6B0C2E3F01427FPQ/2?a $\underline{\text { ccountid }=13480}$

Griffiths, V. (1996). The reflective dimension in teacher education. International Journal of Educational Research, 33(5), 539-555. doi:10.1016/S0883-0355(00)00033-1

Handsfield, L. (2006). Being and becoming American: Triangulating habitus, field, and literacy instruction in a multilingual classroom. Language \& Literacy, 8(2), 1-26.

He, Y., \& Cooper, J. (2011). Struggles and strategies in teaching: Voices of five novice secondary teachers. Teacher Education Quarterly, 38(2), 97-116. 
Henson, R. K. (2001). Teacher efficacy: Substantive implications and measurement dilemmas. Paper presented at the annual meeting of the Educational Research Exchange, University of North Texas, Denton, TX.

Hord, S. M., \& Hall, G. E. (2000). Implementing change: Patterns, principles, and potholes. New York, NY: Allyn and Bacon.

Hoy, A. W. (2000). Changes in teacher efficacy during the early years of teaching. Paper presented at the annual meeting of the American Educational Research Association, New Orleans, LA.

Hoy, A. W., \& Spero, R. B. (2005). Changes in teacher efficacy during the early years of teaching: A comparison of four measures. Teaching and Teacher Education, 21(4), 343356. doi:10.1016/j.tate.2005.01.007

Kafle, N. P. (2011). Hermeneutic phenomenological research method simplified. Bodhi: An Interdisciplinary Journal, 5(1), 181-200.

Klassen, R. M., Tze, V. M. C., Betts, S. M., \& Gordon, K. A. (2011). Teacher efficacy research 1998-2009: Signs of progress or unfulfilled promise? Educational Psychology Review, 23(1), 21-43. doi:10.1007/s10648-010-9141-8

Knoblauch, D., \& Hoy, A. W. (2008). Maybe I can teach those kids. The influence of contextual factors on student teachers' efficacy beliefs. Teaching and Teacher Education, 24(1), 166-179. doi:10.1016/j.tate.2007.05.005

Leithwood, K. (2006). Teacher working conditions that matter: Evidence for change. Toronto, ON: Elementary Teachers' Federation of Ontario.

Larivee, B. (2008). Development of a tool to assess teachers' level of reflective practice. Reflective Practice, 9(3), 341-360. doi:10.1080/14623940802207451

Margolis, J. (2002). Re-form-ing reflection (and action) in English education. English Education, 34(3), 136-214.

Marso, R. N., \& Pigge, F. L. (1995). Outstanding teachers' concerns about teaching at four stages of career development. Educational Review, 18(2), 1-11.

Merriam, S. B. (2004). The role of cognitive development in Mezirow's transformational learning theory. Adult Education Quarterly, 55(1), 60-68. doi:10.1177/0741713604268891

Mezirow, J. (1981). A critical theory of adult learning and education. Adult Education, 21(1), 324.

Mezirow, J. (1991). Transformative dimensions in adult learning. San Francisco, CA: JosseyBass.

Mezirow, J. (1996). Contemporary paradigms of learning. Adult Education Quarterly, 46(3), 158-172. doi:10.1177/074171369604600303 
Mezirow, J. (1997). Transformative Learning: Theory to Practice. New Directions for Adults and Continuing Education, 74, 5-12. doi:10.1002/ace.7401

Mezirow, J. (2000). Learning to think like an adult: Core concepts of transformation theory. In J, Mezirow \& Associates (Eds.), Learning as transformation (pp. 3-34). San Francisco: Jossey-Bass.

Miles, M. B., \& Huberman, A. M. (1994). Qualitative data analysis (2nd ed.). Thousand Oaks, CA: Sage.

Moore, K. B. (2002). From children's services to children's spaces. Public provision, children and childhood. London, UK: Routledge

Moore, W. P., \& Esselman, M. E. (1992). Teacher efficacy, empowerment, and focused instructional climate: Does student achievement benefit? Paper presented at the annual meeting of the American Educational Research Association, San Francisco, CA.

Mulholland, J., \& Wallace, J. (2001). Teacher induction and elementary science teaching: enhancing self-efficacy. Teaching and Teacher Education, 17(2), 243-261. doi:10.1016/S0742-051X(00)00054-8

National Council for Accreditation of Teacher Education (NCATE). (2010). Transforming teacher education through Clinical practice: A national strategy to prepare effective teachers. Retrieved from http://www.ncate.org/

Nolan, A., \& Sim, J. (2011). Exploring and evaluating levels of reflection in pre-service early childhood teachers. Australasian Journal of Early Childhood, 36(3), 122-130.

Organization for Economic Co-operation and Development (OCED) (2011). Building a high quality teaching profession-Lessons from around the world. Background report for the international summit on the teaching profession. Paris, France: OECD. Retrieved from http://www.oecd.org/fr/edu/scolaire/programmeinternationalpourlesuividesacquisdeselev espisa/buildingahigh-qualityteachingprofessionlessonsfromaroundtheworld.htm

Poulou, M. (2007). Personal teaching efficacy and its sources: Student teachers' perceptions. Educational Psychology, 27(2), 191-218.

Poulou, M., Spinthourakis, J. A., \& Papoulia-Tzelepi, P. (2002). Student teachers’ perceptions of their teaching efficacy. Paper presented at the European Conference on Educational Research, Lisbon. Retrieved from http://www.leeds.ac.uk/educol/documents/00002355.htm

Putney, L. G., \& Broughton, S. (2010). Developing teacher efficacy through reflection: A Vygotskian perspective. Critical Issues in Teacher Education, XVII, 4-17.

Richardson, V., \& Placier, P. (2001). Teacher change. In V. Richardson (Ed.) Handbook of research on teaching ( $4^{\text {th }}$ ed., pp. 905-947). Washington, DC: American Educational Research Association.

Schon, D. (1991). Educating the reflective practitioner. San Francisco, CA: Jossey Bass. 
Smith, E. (2011). Teaching critical reflection. Teaching in Higher Education, 16(2), 211-223. doi:10.1080/13562517.2010.515022

Sumsion, J., \& Fleet, A. (1996). Reflection: Can we assess it? Should we assess it? Assessment and Evaluation in Higher Education, 21(2), 121-130. doi:10.1080/0260293960210202

Taylor, E. W. (2007). An update of transformative learning theory: A critical review of the empirical research (1999-2005). International Journal of Lifelong Education, 26(2), 173-191. doi:10.1080/02601370701219475

Taylor, E. W. (2008). Transformative learning theory. New Directions for Adult and Continuing Education, 2008(119), 5-15. doi: 10.1002/ace.301

Tschannen-Moran, M., Woolfolk Hoy, A., \& Hoy, W. K. (1998). Teacher efficacy: Its meaning and measure. Review of Educational Research, 68(2), 202-248. Retrieve from http://www.jstor.org/stable/1170754

Tschannen-Moran, M., \& Woolfolk Hoy, A. (2001). Teacher efficacy: Capturing an elusive construct. Teaching and Teacher Education, 17(7), 783-805. doi:10.1016/S0742051X(01)00036-1

Tschannen-Moran, M., \& Woolfolk Hoy, A. (2007). The differential antecedents of self-efficacy beliefs of novice and experienced teachers. Teaching and Teacher Education, 23(6), 944 956. doi:10.1016/j.tate.2006.05.003

Tripp, D. (1993). Critical incidents in teaching. London, UK: Routledge Falmer.

Usher, E. L., \& Pajares, F. (2009). Sources of self-efficacy in mathematics: A validation study. Contemporary Educational Psychology, 34(1), 89-101. doi:10.1016/j.cedpsych.2008.09.002

Valli, L. (1993). Reflective teacher education programs: An analysis of case studies. In J. Calderhead \& P. Gates (Eds.), Conceptualizing reflection in teacher development (pp. 1122) London, UK: Falmer.

Watske, J. (2007). Longitudinal research on beginning teacher development: Complexity as a challenge to concerns-based stage theory. Teaching and Teacher Education, 23(1), 106122. doi:10.1016/j.tate.2006.04.001

Wheatley, K. F. (2002). The potential benefits of teacher efficacy doubts for educational reform. Teaching and Teacher Education, 18(1), 5-22. doi:10.1016/S0742-051X(01)00047-6

van Manen, M. (1990). Researching lived experience: Human science for an action sensitive pedagogy. Albany, NY: State University of New York Press.

van Manen, M. (1997). Researching lived experience: Human science for an action sensitive pedagogy (2nd ed.). London, ON: The Althouse Press.

Vasquez, A. (2008). Teacher efficacy and student achievement in ninth and tenth grade reading: A multilevel analysis. Unpublished doctoral dissertation, University of South Florida, Tampa, FL. 
Yost, D. S. (2006). Reflection and self-efficacy: Enhancing retention of qualified teachers from a teacher education perspective. Teacher Education Quarterly, 33(4), 59-76. Retrieve from http://www.jstor.org/stable/23478871 